\title{
Adhesive systems modified with antimicrobial agents: a literature review
}

\author{
- Juliana Dias Aguiar School of Dentistry, University of São Paulo, São Paulo, SP, Brazil • Michel Nicolau Youssef \\ School of Dentistry, University of São Paulo, São Paulo, SP, Brazil • Igor Studart Medeiros School of Dentistry, \\ University of São Paulo, São Paulo, SP, Brazil
}

\begin{abstract}
Secondary caries is the primary cause of restoration failure. Thus, the development of adhesives with antimicrobial action is an advantageous option for their inhibition. However, this effect must be proven, as well as that the additional benefit does not interfere with material mechanical properties or biocompatibility. We analyzed adhesives with antimicrobial action by microbiological tests, bond strength, degree of conversion, and cytotoxicity. We analyzed 32 studies with commercially available antimicrobial adhesives (Clearfil ${ }^{\mathrm{TM}} \mathrm{SE}$ Protect Bond/ MDPB, Gluma 2Bond/ glutaraldehyde, Peak Universal Bond/chlorhexidine), and experimental materials or commercial adhesives modified with antimicrobial agents, including materials with quaternary ammonium methacrylate (QAM) [dimethylaminododecyl methacrylate (DMADDM) and dimethylaminohexadecyl methacrylate (DMAHDM)], nanoparticles [silver (NAg), titanium dioxide $\left(\mathrm{TiO}_{2}\right)$, zinc oxide $(\mathrm{ZnO})$ ], silver or zinc doped bioactive active glass (BAG), titanium, copper iodide, and compounds such as triclosan, quercetin, grape seed extract, among others. The use of antimicrobial agents is a favorable perspective for the functionalization of adhesive systems to inhibit secondary caries. However, more clinical studies need to prove the efficacy of these materials.
\end{abstract}

DESCRIPTORS | Dental Caries; Dentin-Bonding Agents; Anti-Bacterial Agents.

RESUMO | Sistemas adesivos modificados com agentes antimicrobianos: uma revisão da literatura • A cárie secundária é a principal causa de falha da restauração. Assim, o desenvolvimento de adesivos com ação antimicrobiana é uma opção vantajosa para sua inibição. No entanto, esse efeito deve ser comprovado, bem como que o benefício adicional não interfere nas propriedades mecânicas do material ou na biocompatibilidade. Analisamos adesivos com ação antimicrobiana por meio de testes microbiológicos, resistência de união, grau de conversão e citotoxicidade. Analisamos 32 estudos com adesivos an-

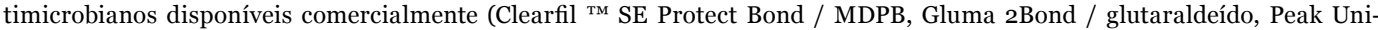
versal Bond / clorexidina) e materiais experimentais ou adesivos comerciais modificados com agentes antimicrobianos, incluindo materiais com metacrilato de amônio quaternário (QAM) [metacrilato de dimetilaminododecil (DMADDM) e metacrilato de dimetilaminohexadecil (DMAHDM)], nanopartículas [prata (NAg), dióxido de titânio ( $\mathrm{TiO}_{2}$ ), óxido de zinco ( $\mathrm{ZnO}_{\text {) }}$ ], vidro bioativo dopado com prata ou zinco (BAG), titânio, iodo de titânio, cobre e compostos como triclosan, quercetina, extrato de semente de uva, entre outros. O uso de agentes antimicrobianos é uma perspectiva favorável para a funcionalização de sistemas adesivos para inibir a cárie secundária. No entanto, mais estudos clínicos precisam provar a eficácia desses materiais.

DESCRITORES | Cáries dentárias; Agentes de ligação à dentina; Agentes Antibacterianos.

CORRESPONDING AUTHOR | - Igor Studart Medeiros School of Dentistry University of São Paulo • Av. Professor Lineu Prestes, 2227 São Paulo, SP, Brazil • 04750-060 E-mail:igorsm@usp.br

- Received Dec. 3, 2019 • Accepted Jan. 16, 2020

- DoI: http://dx.doi.org/10.11606/issn.2357-8041.clrd.2020.164731 


\section{INTRODUCTION}

Secondary caries leads to restoration failure. ${ }^{1-10}$ In the oral environment, the restorative composite undergoes polymerization shrinkage,,$^{9,11-14}$ receives masticatory loads, ${ }^{10,15}$ and accumulates biofilm; ${ }^{8,16}$ being, therefore, susceptible to marginal failure,,$^{10,12,17,18}$ adhesive interface degradation, ${ }^{6,8,10,15,17}$ and micro-infiltration. . $^{1,10,13,15,19}$ Likewise, residual bacteria may remain after cavity preparation, thus inducing the formation of recurrent caries., ${ }^{1,19-21}$ Moreover, some patients are highly prone to develop caries due to low salivary flow, gingival recession, root exposure, hygiene difficulty, and bacterial plaque accumulation. ${ }^{2,22}$ Users of orthodontic appliances are also at high risk, especially around the brackets, where white spot lesions occur. ${ }^{23-30}$

Secondary caries seems to be the main factor for restoration replacement; ${ }^{4-6,9,16,18,31}$ the use of adhesive systems with bioactivity is of interest for the prevention of secondary caries due to their antibacterial effect, inhibiting residual bacteria that may have remained upon cavity preparation, or those that may invade the tooth restoration interface.

Several studies have suggested the development of new antimicrobial adhesives or the incorporation of antimicrobial agents in materials already available in the market. Therefore, this literature review seeks to explore the main results of these studies, analyzing the advances and perspectives of antibacterial adhesive dentistry.

\section{REVIEW}

Firstly, the composition of the substrates that will be attached to these bonding agents must be addressed to understand the characteristics of the adhesive systems. The enamel is a highly mineralized, prismatic structure, consisting of approximately 96\%wt of mineral, organic matter, and water. ${ }^{32}$ It is a substrate highly favorable to adhesion due to its homogenous composition. ${ }^{33,34}$ The dentin, on the other hand, is composed of approximately 50\% organic matter,
$30 \%$ organic matrix, and $20 \%$ water, as far as the volume is concerned. ${ }^{13,35,36}$ In morphological terms, the dentin may be peritubular or intertubular. The peritubular dentin is mainly composed of apatite crystals and little organic content; so, it is more mineralized than the intertubular dentin, which, in turn, consists of a collagen matrix, mainly type I, with carbonated apatite crystals. ${ }^{33}$ The dentinal tubules orientation and density vary according to their location. Near the amelo-cement junction, there are few tubules of smaller diameter, exhibiting less permeability. Near the pulp, these tubules increase in quantity and amplitude; thus, increasing dentin permeability. ${ }^{33,36}$ Besides, extensions of the odontoblasts are inside the tubules, establishing a connection with the pulp. This substrate is then a challenge to Adhesive Dentistry due to its complex constitution. ${ }^{33}$ The substrate structure and permeability are directly related to resin-based materials adhesion capability. ${ }^{36}$ Higher bond strength values are observed in the superficial dentin; on the other hand, lower bond strength values are found in the deep dentin, which is more permeable..$^{36}$

The adhesive systems aim to form a bond between the substrate (enamel and dentin) and the restorative material, either direct or indirect. Thus, the adhesive will establish the desired adhesion to the substrate by either micromechanical retention or chemical bonding, or both. Initially, they were classified according to their generations. Currently, they are divided considering the type of smear layer treatment and their number of steps, etch-and-rinse (2 or 3 steps), and self-etch systems (1 or 2 steps), respectively. ${ }^{14,33,37}$ However, a new class emerged, which allows the combination of both strategies, the "universal adhesives" ${ }^{37,38}$

The basic components of the adhesive system are: conditioning agent, primer and adhesive, in addition to photo initiators, polymerization inhibitors, and inorganic fillers. ${ }^{33}$ They can also be modified with

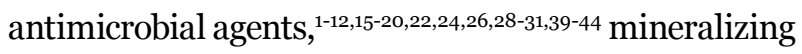


agents, ${ }^{2,3,16,22,26,30,45}$ protein repellent, ${ }^{2}$ inhibitors of metalloproteinases, ${ }^{6,46,47}$ and even inti-inflammatory agents. ${ }^{5}$ The understanding of the function of each system component and their careful use, respecting their indications, will be essential for adhesion success.

In the etch-and-rinse systems, the conditioning agent is generally $37 \%$ phosphoric acid, which aims to demineralize both enamel and dentin and create microporosities, ${ }^{14,37}$ which will favor the micromechanical retention. Moreover, the acid increases the enamel surface energy, favors the wetting of resinous monomers, ${ }^{33}$ and exposes the network of dentin collagen. ${ }^{37}$

The primer consists of hydrophilic monomers, mainly 2-hydroxy-ethyl methacrylate (HEMA), associated with a solvent, which may be water, acetone, or ethanol. ${ }^{14,37}$ It establishes the bond between the exposed collagen, which is hydrophilic, with the resinous matrix of the adhesive, which is hydrophobic. ${ }^{33}$ It should also keep the collagen network expanded and displace the excess water so that the monomers can infiltrate the substrate. ${ }^{33,37}$

Self-etch systems contain the HEMA, solvent, and acidic monomers [10-methacryloyloxydecyl phosphate (10-MDP), 4-methacryloyloxyethyl trimethyl (4-MET), and methacryloyloxy-ethyl (phenyl-P)]. Acidic monomers promote conditioning, infiltrate the substrate and have the ability to bind to the calcium of the hydroxyapatite chemically. $33,35-37$

The adhesives are composed of hydrophobic monomers such as the bisphenol glycidyl methacrylate (Bis-GMA), ethylene glycol dimethacrylate (TEGDMA), urethane dimethacrylate (UDMA), among others that establish a primary bond to HEMA, and on the other side, bind to the resin matrix of the restorative composite. ${ }^{33}$ Adhesion requires inorganic tooth material replacement by a polymeric material, incorporating the adhesive resin into the substrate and forming the hybrid layer. ${ }^{14,33,36,37,48}$

Etch-and-rinse adhesives can be divided into three or two-step types. Those of three steps consist of acid conditioning, primer, and bonding application, ${ }^{14,37,49}$ which is considered the gold standard adhesion technique. ${ }^{32}$ By separating the stages of different components with different mechanisms of action, one step can benefit the most from the others. ${ }^{14,33}$ On the other hand, two-step adhesives include the application of acid etching, followed by a single-bottled primer/bonding, which binds hydrophilic, hydrophobic, and solvent components in one step. . $^{14,33,36,37,49}$

In etch-and-rinse adhesives, some water remains after acid etching and washing. Regarding the enamel, drying it to obtain an opaque and whitish appearance is an ideal condition for adhesion. ${ }^{33}$ However, dentin should remain slightly moist after etch and rinse due to its constitution. This issue is very subjective and makes the technique extremely sensitive, since removing water results in collagen fibers collapse and resinous monomers penetration difficulty. ${ }^{13,37}$ On the other hand, excess water in dentin solubilizes the monomers, hindering their penetration in the interfibrillar spaces and impairing their conversion degree. ${ }^{13,32,34}$

The two steps self-etch adhesives, in turn, consist of acidic primer, followed by bond application, whereas in the single-step type, acid, primer, and bonding are applied at once..$^{14,33,37,49}$ These systems are further subdivided into categories according to their $\mathrm{pH}$ and depth of interaction with dentin. Ultra-soft self-etching ( $\mathrm{pH}>2.5$ ) presents hybrid layer (HL) depth of 0.2-0.5 $\mu \mathrm{m}$; the moderate ones ( $\mathrm{pH} 2$ ), approximately $0.5^{-1}$ $\mu \mathrm{m}$ HL depth; intermediate (pH 1-2), and HL of 1-2 $\mu \mathrm{m}$ depth; and strong $(\mathrm{pH} \leq 1)$ at $\mathrm{a} \geq 0.5 \mu \mathrm{m}$ penetration depth. ${ }^{88,48}$ According to the "adhesion-decalcification" concept, when a moderate $\mathrm{pH}$ system is used, ionic bonds show more stability due to the association of resinous monomers with the calcium salt; therefore, a hydrolytically durable joint is established..$^{48}$ However, when using a strong $\mathrm{pH}$-adhesive, the ionic bonds are not stable, leading to ion release, 
consequent tooth decalcification and, finally, adhesive interface weakening. ${ }^{48}$

In self-etching adhesives, there is no washing stage, so the subjectivity regarding the amount of moisture left in the dentin is eliminated in these systems. Moreover, the reduction in the steps simplifies the adhesion process and makes these adhesives less sensitive to the technique. ${ }^{14,48}$ These systems condition and promote adhesion, so that the smear layer is incorporated into the hybrid layer, reducing the risk of incomplete monomer penetration in the substrate and the presence of voids at the interface, and also reducing the chance of postoperative sensitivity. ${ }^{14,32,33,48,50}$ Finally, the functional monomers may chemically interact with the dentin; therefore, in addition to a micromechanical adhesion, a chemical bond is established with the substrate. ${ }^{33,34,48}$ However, they do not work very well on the enamel due to their highly mineralized nature. Thus, whenever the enamel is involved, their conditioning with phosphoric acid, followed by washing, is recommended for adhesion improvement. ${ }^{34}$

The last and most recent category of adhesive systems is called "universal". Through a multimode proposal to further facilitate clinical routine, the operator can choose to use that material according to the etch-and-rinse technique or selfetch. ${ }^{34,38,51}$ But, whenever the preparation involves the enamel, the selective enamel conditioning is still recommended. ${ }^{34,38,51}$ Given the versatility of such materials, literature often questions whether old problems of Adhesive Dentistry have been solved, such as problems related to metalloproteinase (MMPs) and cathepsinmediated degradation of collagen or the presence of nano-infiltration, which promotes the hydrolytic degradation of the hybrid layer. ${ }^{38,50}$

Adhesive Dentistry also expects the new materials to have additional benefits over what they are originally intended, leading to therapeutic action. However, such benefits must be promoted without reducing the material mechanical properties and biocompatibility. Thus, in the last years, several studies have been developed to favor the antimicrobial action of adhesives in order to inhibit secondary caries that could compromise the adhesive interface durability. ${ }^{1-12,15-20,22,24,26,28-31,39-44}$

Caries disease remains the main reason for restorations failure, requiring its subsequent replacement. ${ }^{2,4,9,16,18,19,52,53}$ One mechanism by which caries can affect the durability of restorations is related to biofilm accumulation on resinous restorative materials. ${ }^{8,16,5^{2}}$ Therefore, the microbial colonization begins from the acquired film (protein layer from the saliva), forming the oral biofilm. ${ }^{2,52}$ The bacteria use dietary carbohydrates for their metabolism and produce acids that lead to $\mathrm{pH}$ reduction and teeth demineralization. $., 9,15,16,19,26,52$ When this process occurs in a previously restored interface, it receives the denomination of caries adjacent to the restoration or secondary caries.9,52

Many researchers develop new antimicrobial adhesives, or modify the materials available in the market with the addition of antimicrobial agents as a resort to secondary caries inhibiting mechanisms. ${ }^{1-12,15-20,22,24,26,28-31,39-44}$ Thus, the addition of benefit with potential to increase restoration longevity is desired..$^{16,52}$

In this context, nanotechnology has been used in caries prevention. Nanoparticles $(<100 \mathrm{~nm})$ are synthesized to optimize the properties of the materials by increasing the surface area, chemical reactivity, and biological activity. ${ }^{15,52,54,55}$ One of the classic examples is the use of silver nanoparticles (NAg) ${ }^{24,39,45,56}$ of antibacterial, antifungal, and antiviral action. ${ }^{40,52}$

NAg mechanism of action seems to be based on the action of positively charged ionic silver, which in contact with the negatively charged bacterial cell, promotes an osmotic alteration and causes the bacterial membrane rupture, resulting in cell death. ${ }^{52,54}$ Moreover, silver ions are suggested to 
inactivate vital bacterial enzymes and inactivate DNA ability to replicate, resulting in bacterial death. ${ }^{22,54,55}$

NAg synthesis techniques include reduction of the silver salt to produce silver nanoparticles (NAg) directly in methacrylate monomers, such as 2-terbutylamino ethyl methacrylate (TBAEMA), which are then mixed with adhesive monomers. ${ }^{15,52,55}$ This procedure eliminates the need to incorporate the nanoparticles stabilized with different components in the adhesive, which can form agglomerates and causes the bacterial agent to be trapped in the polymer matrix. Finally, this technique prevents NAg from being released from the material, which would jeopardize its antibacterial effect and the mechanical properties of the material..$^{52,55}$

Furthermore, there is a class of antibacterial monomers, based on ammonium quaternary methacrylates (QAMs), such as 12-methacryloyloxydodecylpyridinium bromide (MDPB), ${ }^{12,17,20,27,42,44}$ the first commercially available antibacterial monomer (Clearfil SE Protect, Kuraray), ${ }^{57,58}$ methacryloxyethyl cetyl dimethyl ammonium chloride (DMAECB) ${ }^{53}$, dimethylaminododecyl methacrylate (DMADDM), ${ }^{1,3,4,7,16,19}$ dimethylaminohexadecyl methacrylate (DMAHDM), 2,4,15,22 2-methacryloxyethyl dodecyl methyl ammonium bromide (MAE-DB), ${ }^{10}$ 2-methacryloxyethyl hexadecyl methyl ammonium (MAE-HB) ${ }^{29}$, and poly (dimethylaminoethyl) methacrylate-cooctyldimethyl ammonium ethyl methacrylate bromide-co-methyl methacrylate-co-butyl, ${ }^{20}$ among others. These antibacterial monomers copolymerize with the monomers present in the adhesive system; thus, they have a mechanism of action by contact and do not lose their effectiveness, since they are incorporated in the polymeric matrix. ${ }^{15}$
Other antibacterial strategies incorporated into dental biomaterials include titanium dioxide $\left(\mathrm{TiO}_{2}\right),{ }^{24}$ zinc oxide ( $\mathrm{ZnO}),{ }^{24}$ bio-active glass (BAG) doped with $\mathrm{Ag}_{2} \mathrm{O}$ or $\mathrm{ZNO},{ }^{26}$ silver methacrylate (Ag), ${ }^{40}$ di-n-butildimetacrilatetin (Sn), ${ }^{40}$ nanoparticulate with titanate metal complex (nMT), ${ }^{43}$ polyacrylic acid copper iodine (PAA-CuI), ${ }^{17}$ arginine, ${ }^{9}$ nisin peptides,${ }^{18}$ [2 (methacryloyloxy) ethyl] trimethylammonium chloride (METAC or MADQUAT) ${ }^{28,41}$, 2- [3-2H-benzotriazol-2yl) -4-hydroxyphenyl] ethyl methacrylate (BTAM) ${ }_{11}^{11}$ epigallocatechim-3-gallate (EGCG), ${ }^{8}$ epigallocatechim-3-O- (3-O-methyl) -galate (EGCG-3Me), ${ }^{8}$ 1,3,5-triacryloylhexahydro1,3,5-triazine (triazine) ${ }^{30,31}$, glutaraldehyde,,$^{12,44}$ chlorhexidine (CHX), ${ }^{12,44}$ nanocapsules of triclosan, ${ }^{5}$ quercetin, ${ }^{6}$ natural essential oils. ${ }^{59}$

The use of antimicrobial agents pre-treating the dentin before adhesive procedures are poly ( $\varepsilon$-prolactone) nanocapsules loaded with chlorhexidine (nano PCL/ CHX), ${ }^{47}$ nanoparticles of poly (lactic-co-glycolic acid) loaded with chlorhexidine (nano PLGA-CHX), ${ }^{46}$ and grape seed extract (e-GSE). ${ }^{60}$

\section{RESULTS}

We used the PUBMED database to obtain articles from 2014 to 2019, using the keywords: dental adhesives AND antibacterial and dental adhesives AND antimicrobial. Literature reviews, systematic reviews, case series, editorials, studies without a suitable control group, articles that evaluated the effect of antibacterial agents in dental materials other than adhesives or isolated were excluded. Thirty-four studies of adhesives containing antimicrobial agents were selected. Table 1 shows commercial adhesives and their respective manufacturers and composition. The main results of the studies are described in Table 2. 
Table 1 | Commercial dental adhesives addressed in the study, with their respective manufacturers, composition, classification, and antimicrobial agent

\begin{tabular}{|c|c|c|c|c|}
\hline $\begin{array}{l}\text { Commercial } \\
\text { adhesive }\end{array}$ & Manufacturer & Composition & Classification & $\begin{array}{l}\text { Antimicrobial } \\
\text { agent }\end{array}$ \\
\hline $\begin{array}{l}\text { Adper Single } \\
\text { Bond } 2\end{array}$ & $3 \mathrm{M}$ & $\begin{array}{l}\text { Bis-GMA, HEMA, polyalkanoic acid copolymer, } \\
\text { photo initiators, ethanol, water. }{ }^{8}\end{array}$ & $\begin{array}{l}\text { Two-step etch- } \\
\text { and-rinse }\end{array}$ & - \\
\hline All-Bond $2^{\mathrm{TM}}$ & Bisco & $\begin{array}{l}\text { Primer A: 50-75\% acetone, 10-30\% ethanol, 1-5\% NTG-GMA sodium. } \\
\text { Primer B: Ethanol, acetone, 2-hydroxyethyl methacrylate, 3,4,3 ‘, } \\
\text { 4-biphenyltetracarboxylic anhydride (Source: Bisco Data Sheet). }{ }^{61}\end{array}$ & $\begin{array}{l}\text { Three-step } \\
\text { etch-and-rinse }\end{array}$ & - \\
\hline $\begin{array}{l}\text { ClearfiliM SE }^{\mathrm{TM}} \\
\text { Bond }\end{array}$ & Kuraray & $\begin{array}{l}\text { Primer: 2-hydroxyethyl methacrylate, dihydrogen 10-methacryloyloxydecyl } \\
\text { phosphate, hydrophilic aliphatic dimethacrylate, di-camphorquinone, } \\
\text { water, accelerators, dyes, others. Bond: Bisphenol A diglycidyl } \\
\text { methacrylate, 2-hydroxyethyl methacrylate, dihydrogen } \\
\text { 10-methacryloyloxylate, hydrophobic aliphatic methacrylate, colloidal } \\
\text { silica, di-camphorquinone, initiators, accelerators, others. }{ }^{44}\end{array}$ & $\begin{array}{l}\text { Two-step self- } \\
\text { etch }\end{array}$ & - \\
\hline $\begin{array}{l}\text { Clearfil'TM SE }^{\mathrm{TM}} \\
\text { Protect Bond }\end{array}$ & Kuraray & $\begin{array}{l}\text { Primer: 2-hydroxyethyl methacrylate, } \\
\text { dihydrogen 10-methacryloyloxydecyl phosphate, } \\
\text { 12-methacryloyloxydodecylpyridinium bromide (MDPB), hydrophilic } \\
\text { aliphatic dimethacrylate, water, initiators, accelerators, colorants, } \\
\text { others. Bond: Bisphenol A diglycidyl methacrylate, 2-hydroxyethyl } \\
\text { methacrylate, sodium fluoride, dihydrogen 10-methacryloyloxylate, } \\
\text { hydrophobic aliphatic methacrylate, colloidal silica, di-camphorquinone, } \\
\text { initiators, accelerators, others. }{ }^{44}\end{array}$ & $\begin{array}{l}\text { Two-step self- } \\
\text { etch }\end{array}$ & MDPB \\
\hline Gluma 2Bond & $\begin{array}{l}\text { Heraeus } \\
\text { Kulzer }\end{array}$ & $\begin{array}{l}\text { Ethanol, 2-hydroxy-methyl methacrylate, poly (acrylic acid oligo- } \\
\text { methacrylic acid), 4-methacryloxyethyltrimellitic acid anhydrate, } \\
\text { glutaradeide, amorphous silica. }{ }^{44}\end{array}$ & $\begin{array}{l}\text { Two-step etch- } \\
\text { and-rinse }\end{array}$ & Glutaraldehyde \\
\hline $\begin{array}{l}\text { Gluma } \\
\text { Comfort Bond }\end{array}$ & $\begin{array}{l}\text { Heraeus } \\
\text { Kulzer }\end{array}$ & $\begin{array}{l}\text { Ethanol, 2-hydroxyethyl methacrylate, poly (acrylic acid oligo- } \\
\text { methacrylic acid), 4-methacryloxyethyl trimeric acid anhydrate. }{ }^{44}\end{array}$ & $\begin{array}{l}\text { Two-step etch- } \\
\text { and-rinse }\end{array}$ & - \\
\hline $\begin{array}{l}\text { Optibond Solo } \\
\text { Plus }\end{array}$ & Kerr & $\begin{array}{l}\text { Bis-GMA, HEMA, GPDM, ethanol, barium aluminum borosilicate glass, } \\
\text { silicon dioxide, sodium hexafluorum silicate, camphorquinone. } .^{17}\end{array}$ & $\begin{array}{l}\text { Two-step etch- } \\
\text { and-rinse }\end{array}$ & - \\
\hline Optibond XTR & Kerr & $\begin{array}{l}\text { Primer: } 30-50 \% \text { HEMA, } 25-35 \% \text { acetone, } 4-15 \% \text { ethyl alcohol. Bond: } \\
20-30 \% \text { ethyl alcohol, } 47-68 \% \text { resin alkyl dimethacrylate, } \\
5-15 \% \text { barium aluminoborosilicate glass, } 3-10 \% \text { silicon dioxide, } \\
0.5-3 \% \text { sodium hexafluorosilicate. }{ }^{17}\end{array}$ & $\begin{array}{l}\text { Two-step self- } \\
\text { etch }\end{array}$ & - \\
\hline Peak LC Bond & Ultradent & $\begin{array}{l}\text { 2-hydroxyethyl methacrylate, methacrylic acid, ethyl-4-dimethylamino } \\
\text { benzoate, ethyl alcohol. }{ }^{44}\end{array}$ & $\begin{array}{l}\text { Two-step etch- } \\
\text { and-rinse }\end{array}$ & - \\
\hline $\begin{array}{l}\text { Peak Universal } \\
\text { Bond }\end{array}$ & Ultradent & $\begin{array}{l}\text { Ethyl alcohol, } 2 \text {-hydroxyethyl methacrylate, methacrylic acid, } \\
0.2 \% \text { chlorhexidine diacetate. }{ }^{44}\end{array}$ & Universal & Chlorhexidine \\
\hline $\begin{array}{l}\text { Prime \& Bond } \\
\text { NT }\end{array}$ & Dentsply & $30 \%$ methacrylates, $10 \%$ methyl methacrylate, $60 \%$ acetone. ${ }^{22}$ & $\begin{array}{l}\text { Two-step etch- } \\
\text { and-rinse }\end{array}$ & - \\
\hline $\begin{array}{l}\text { Scotchbond } \\
\text { Multi-Purpose } \\
\quad \text { (SBMP) }\end{array}$ & $3 \mathrm{M}$ & $\begin{array}{l}\text { Primer: } 35-45 \% \text { HEMA, } 10-20 \% \text { of an acrylic and } \\
\text { itacomic acid copolymer, } 40-50 \% \text { water. Bond: } 60-70 \% \text { BisGMA, } \\
30-40 \% \text { HEMA, tertiary amine and photo initiator. }{ }^{62}\end{array}$ & $\begin{array}{l}\text { Three-step } \\
\text { etch-and-rinse }\end{array}$ & - \\
\hline $\begin{array}{l}\text { Transbond } \\
\text { XT }\end{array}$ & $3 \mathrm{M}$ & $\begin{array}{l}\text { Primer: } 40-55 \% \text { Bisphenol A diglycidyl ether dimethacrylate (BISGMA), } \\
\text { 45-55\% triethylene glycol dimethacrylate, triphenylantimoni, } \\
\text { 4- (dimethylamine) benzene ethanol, dl-camphorquinone, } \\
\text { hydroquinone. Adhesive: } 70-80 \% \text { silane treated quartz, } 10-20 \% \\
\text { bisphenol A diglycidyl ether dimethacrylate (BISGMA), 5-10\% bisphenol } \\
\text { A bis (2-hydroxyethyl ether) dimethacrylate, silane-treated silica, } \\
\text { diphenyl iodonium hexafluorophosphate (Source: } 3 \text { M Data Sheet). }{ }^{63}\end{array}$ & $\begin{array}{l}\text { Three-step } \\
\text { etch-and-rinse }\end{array}$ & - \\
\hline XP Bond & Dentsply & $\begin{array}{l}\text { TCB resin, PENTA, UDMA, TEGDMA, HEMA, butylated benzenediol, ethyl-4- } \\
\text { dimethylaminobenzoate, camphorquinone, amorphous silica, t-butanol. }{ }^{17}\end{array}$ & $\begin{array}{l}\text { Two-step etch- } \\
\text { and-rinse }\end{array}$ & - \\
\hline
\end{tabular}




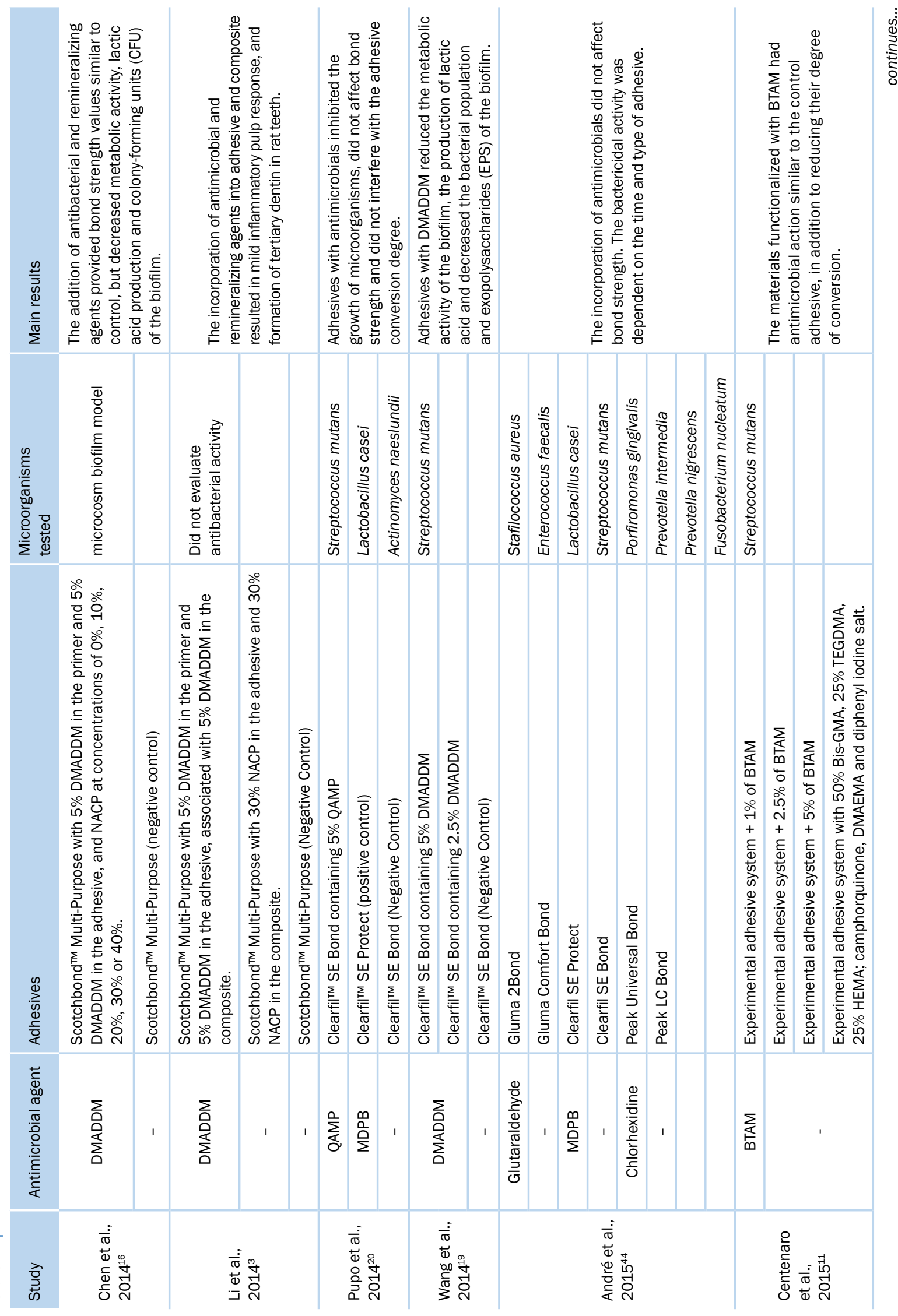




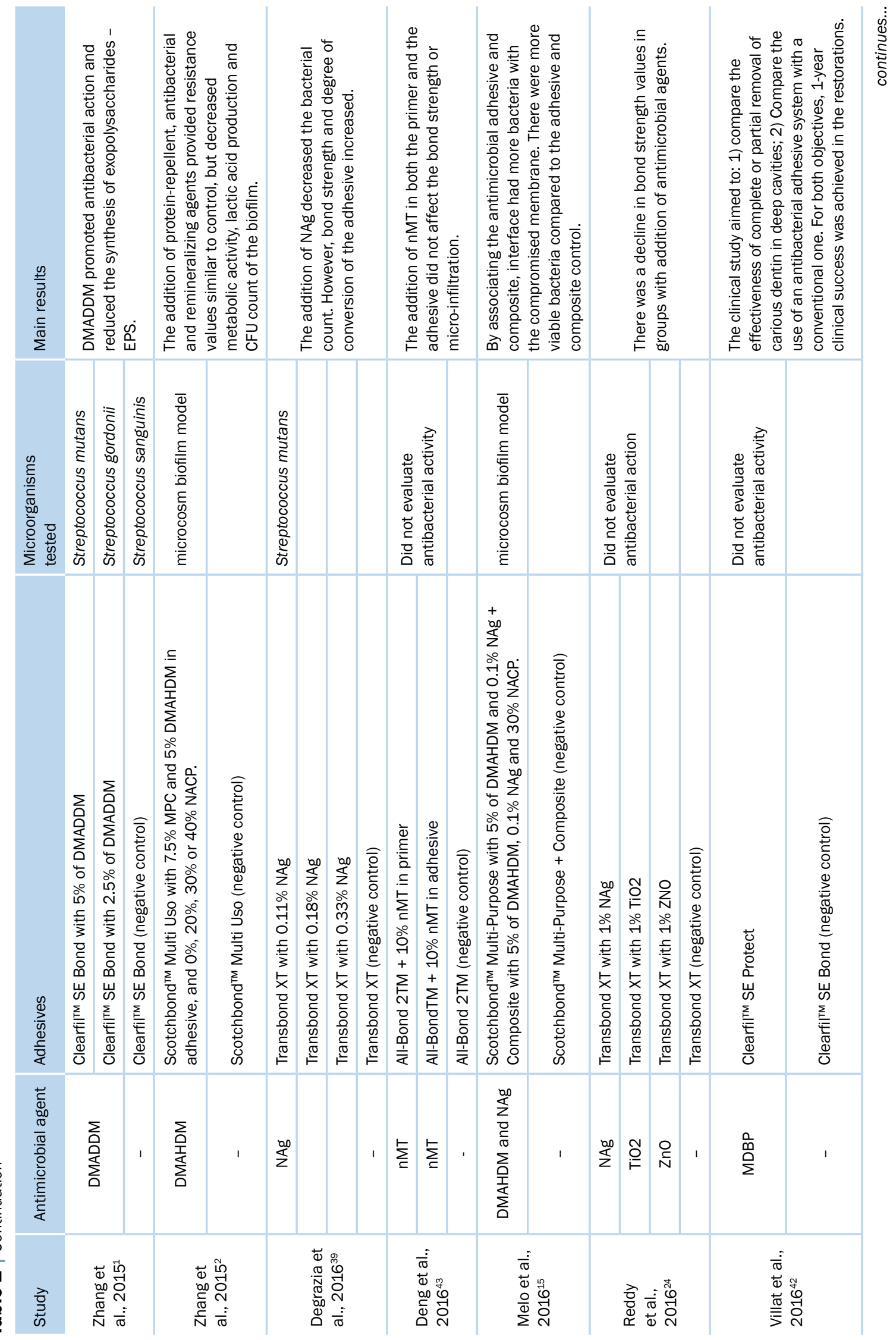




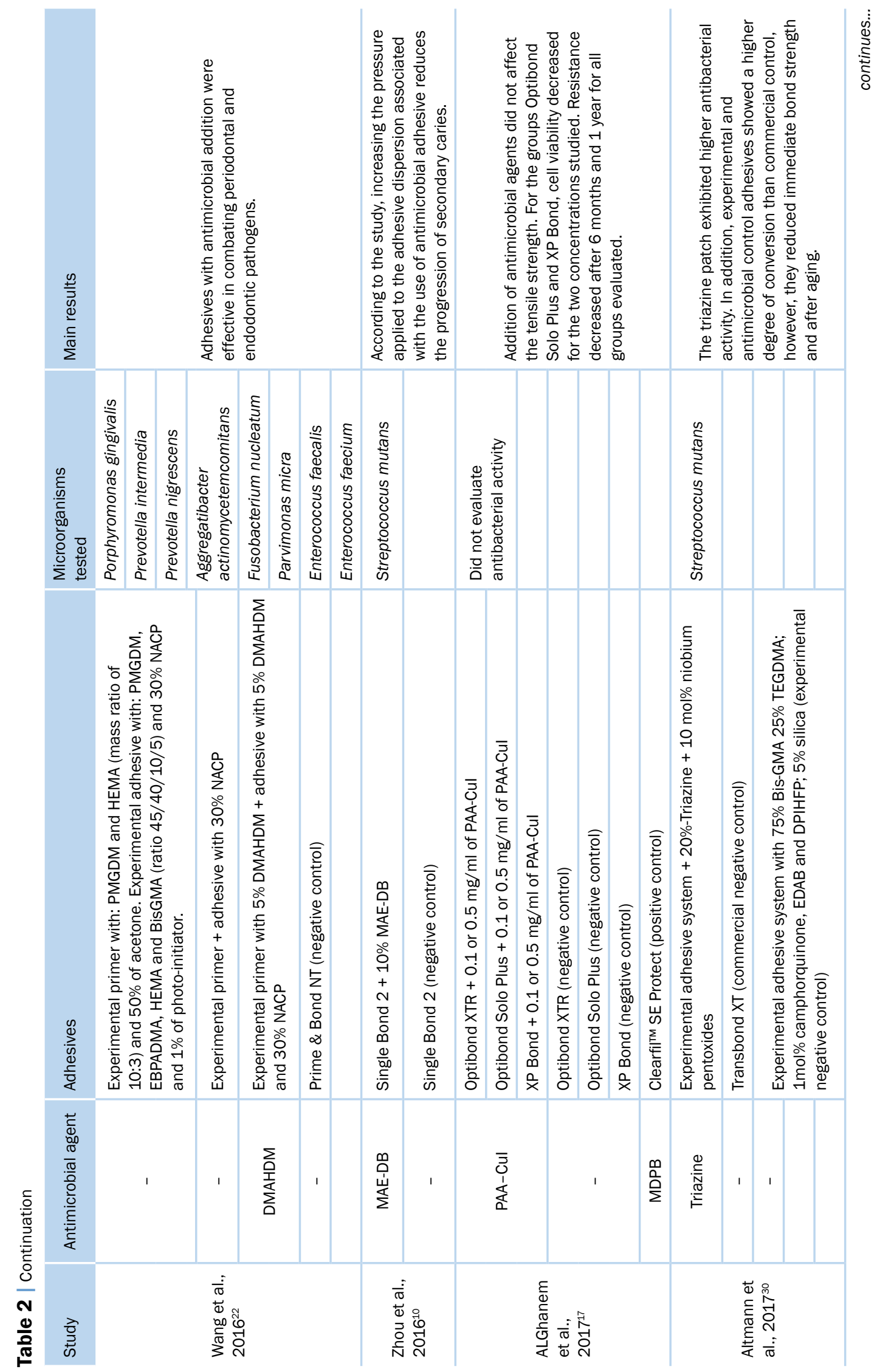




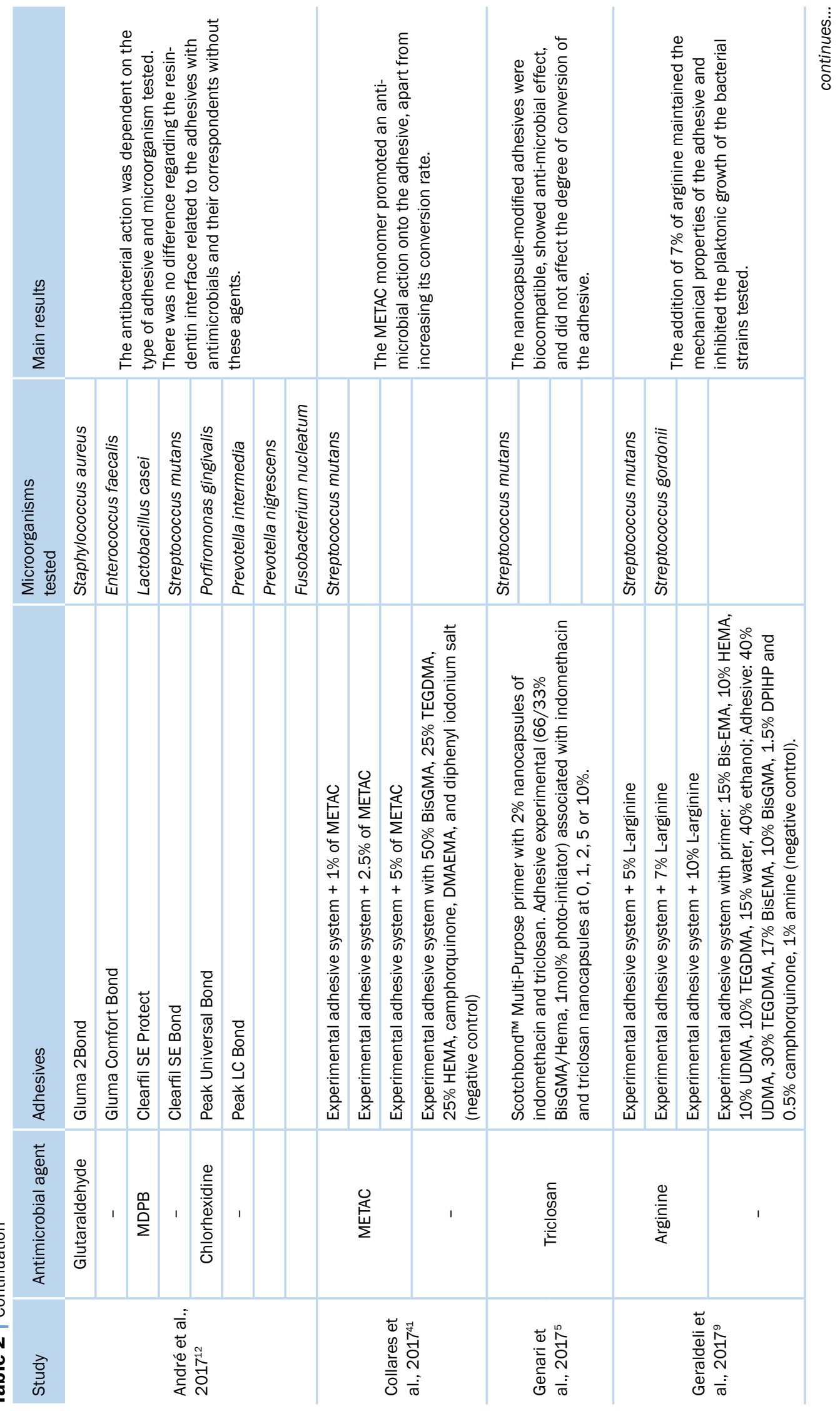




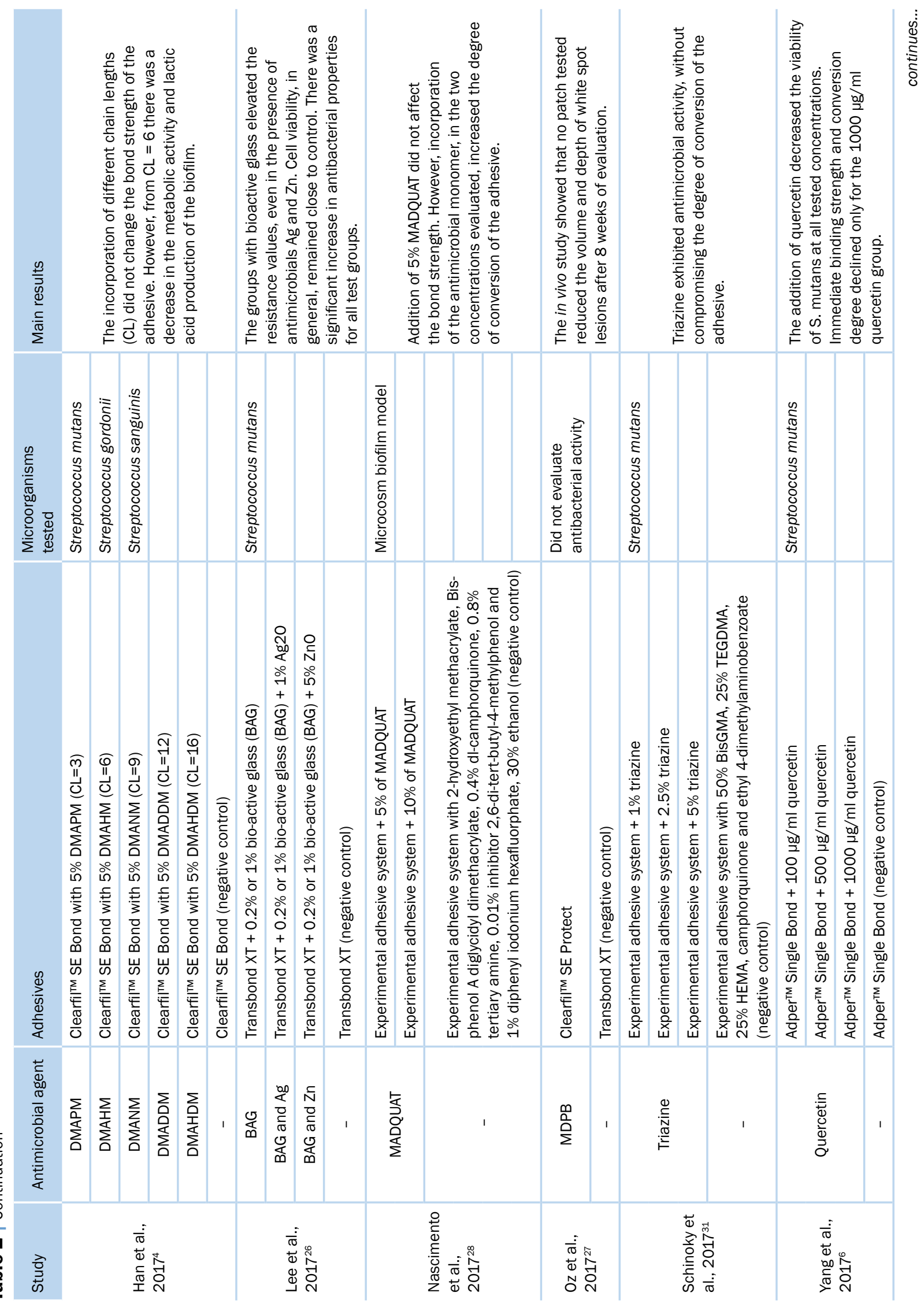



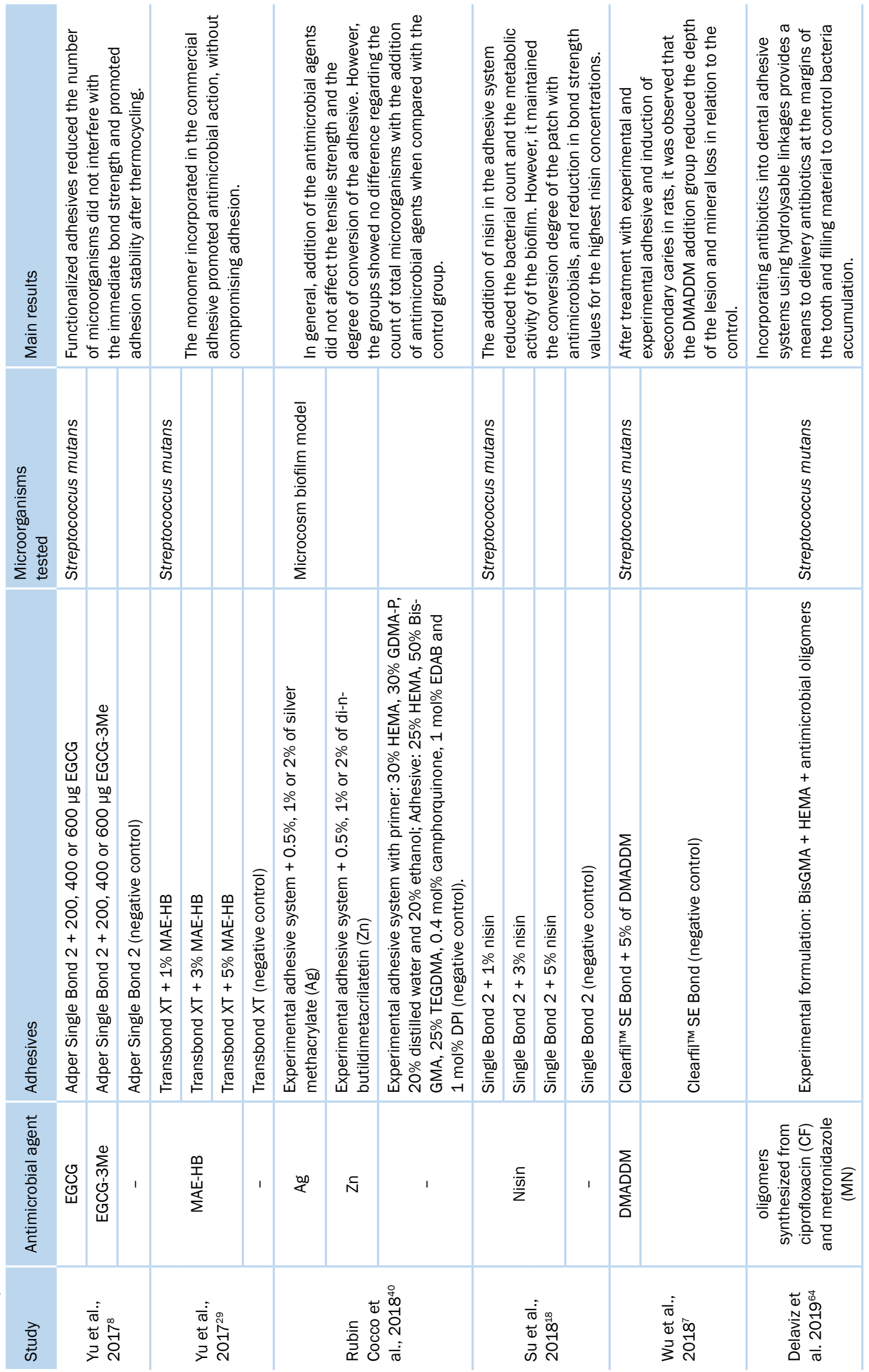


\section{DISCUSSION}

We analyzed studies showing that the adhesives presented antibacterial activity without affecting the mechanical properties or compromising their biocompatibility, being promising to inhibit secondary caries. Thirty-two studies with antimicrobial agents in adhesives from 2014 to 2018 were analyzed: 28 studies in vitro; 2 studies used animal models, one of which did not evaluate antimicrobial effects, but the pulp inflammatory response, ${ }^{3}$ and the other performed restorations on rats with antimicrobial adhesives (DMADDM), and after inducing secondary caries, measured mineral loss and depth of injury; 7 and 2 in vivo, one of which was aimed at evaluating the success of restorations after complete or partial removal of carious dentin with the subsequent use of antimicrobial (MDPB) or conventional adhesive,,$^{42}$ and the other evaluated the demineralization of the enamel after 8 weeks of the brackets cementation with antibacterial and fluoride adhesive (Clearfil Protect Bond). ${ }^{27}$ Moreover, some of these studies used experimental adhesives; ${ }^{9,11,22,28,30,31,40,41}$ others used commercially available antimicrobial adhesives, such as Clearfil Protect Bond (MDPB), ${ }^{12,17,20,27,42,44}$ Gluma 2 Bond (glutaraldehyde), ${ }^{12,44}$ and Peak universal bond (chlorhexidine); ${ }^{12,44}$ or conventional commercial adhesives combined with antimicrobial agents. . $-8,10,15-20,24,26,29,39,42,43$ Therefore, given the diversity of new agents of union with antimicrobial activity, the analysis of the results of these studies requires caution. Hence, well-conducted clinical studies and long-term analysis may validate their use as secondary caries inhibitors.

Different methods to evaluate antibacterial activity are available, such as the diffusion test on agar, ${ }^{12,18,23,29,39,40,44}$ biofilm activity measured by (3-(4,5-Dimethylthiazol-2-yl)-2,5Diphenyltetrazolium Bromide) (MTT), 4,16,19,22 production of lactic acid, ${ }^{1,4,16,19}$ counting of colony forming units (UFC), ${ }^{1,5,11,16,22,31,40,41}$ analysis of biofilm exopolysaccharides (EPS) by confocal laser scanning microscopy (MVLC) ${ }^{1,19}$ or using a spectrophotometer, ${ }^{22}$ minimum inhibitory concentration (ICM), ${ }^{20}$ minimum bactericidal concentration (MCB), ${ }^{20}$ epifluorescence live/dead test, ${ }^{2,22}$ or MVLC, ${ }^{1,4,6,8,9,16,18,19,29}$ scanning electron microscopy (SEM), 2,4,8,12,17,19,29 and molecular techniques such as real-time polymerase chain reaction (q-PCR). ${ }^{1}$ Many studies have used only $S$. mutans to estimate bacterial activity, ${ }^{-8,8,10,11,18,19,26,29-31,39,41}$ which is the main etiological agent of dental caries. However, the use of a microcosm biofilm model ${ }^{2,15,16,28,40}$ is closer to clinical reality, considering the diversity and complexity of microorganisms present in the oral cavity. ${ }^{28}$

Moreover, using microorganisms in biofilms seems more appropriate than in planktonic form, since planktonic microorganisms are a thousand times more susceptible to antimicrobial action than when they form biofilm..$^{52}$ The study that incorporated $7 \%$ of arginine into adhesive 9 inhibited the planktonic growth of the strains tested; however, the use of biofilm is the ideal to evaluate the real antimicrobial potential. Among the antimicrobial substances, some are metals such as $\mathrm{Ag},{ }^{15,24,26,39,40} \mathrm{TiO}_{2},{ }^{24} \mathrm{Zn},{ }^{24,26,40} \mathrm{nMT}$, ${ }^{43}$ PAA-CUI; ${ }^{17}$ others are part of the quaternary ammonium methacrylate group (QAM) as MDPB,,$^{12,17,20,27,42,44}$ which was the first antibacterial monomer incorporated into a commercial adhesive, in addition to DMADDM, ${ }^{1,3,4,7,16,19}$ DMAHDM, ${ }^{2,4,15,22}$ QAMP; ${ }^{20}$ and other agents such as glutaraldehyde, ${ }^{12,44}$ chlorhexidine, ${ }^{12,44}$ triazine, ${ }^{30,31}$ triclosan, ${ }^{5}$ arginine, ${ }^{9}$ quercetin, ${ }^{6}$ EGCG,${ }^{8}$ EGCG-3Me,${ }^{8}$ nisin, ${ }^{18}$ among others.

Antibacterial action mechanism occurs through the ionic release in some materials, especially in metal compounds, so the positive charge of the antibacterial agent in contact with the negative charge of the bacterial membrane increases the membrane bacterial permeability, rupture and cell death..$^{2}$ For agents such as QAM, the mechanism of inhibition is by contact, since the antibacterial monomer copolymerizes with the monomers of the adhesive system and is attached to the polymer matrix. ${ }^{37,75,19}$ Most of the studies reported immediate 
antibacterial action, or analysis for up to one year of aging. 1,6,8,16-18,20,28-30,39,40,43,44

Antimicrobial potential is also influenced by the adhesive $\mathrm{pH} .{ }^{21}$ Adhesives with low $\mathrm{pH}$ exhibit antimicrobial action, whether or not associated with antimicrobial agents. ${ }^{21}$ Modified binding agents also have the purpose of being used in orthodontic adhesives. Users of orthodontic devices are more likely to have white spot lesions, since orthodontic devices accumulate more biofilm. . $^{23,24,26,27,39}$

To potentiate the antimicrobial action, several studies associate more than one antimicrobial agent within adhesives, such as NAg and DMAHDM, ${ }^{15}$ or added an antimicrobial to a remineralizing agent such as amorphous calcium phosphate, ${ }^{2,3,16}$ in addition to integrating protein-repellent agents like the MPC. ${ }^{2}$ QAMs with different alkyl chain lengths were also tested, which showed that the increase in the chain increases the hydrophobicity, thus facilitating the penetration into the bacterial cell membrane. ${ }^{4}$

In addition to decreasing the viability of microorganisms, the modified adhesives do not negatively affect mechanical properties such as the bond strength th,8, $, 16,17,20,26,29,40$ and the degree of conversion (GC) of the material.5,9,18,20,28,30,31,40,41 We showed that adhesives with 5\%-QMAP and $\mathrm{MDPB}^{20}$ and chlorhexidine binding agents did not interfere with bond strength, not even after 1 year of storage compared to their counterparts with no antimicrobial substances. ${ }^{44}$ Moreover, the incorporation of DMADDM, ${ }^{16}$ DMAHDM, ${ }^{2}$ nMT, ${ }^{43}$ EGCG,${ }^{8}$ EGCG-3Me,${ }^{8}$ MAE-HB,${ }^{29}$ silver methacrylate, $\mathrm{Zn},{ }^{40}$ and different QAM chain lengths ${ }^{4}$ did not interfere with material strength. However, shear strength decreased due to the inclusion of NAg in the Transbond XT, in concentrations between $0.11 \%$ to $0.33 \%$, as well as with GC. ${ }^{39}$ Regarding this same adhesive, the addition of $1 \%-\mathrm{NAg}$, TiO2, or $\mathrm{ZnO}$ promoted bond strength decrease. ${ }^{24}$ Furthermore, the addition of 3 to $5 \%$-nisin in Single Bond 2 reduced its micro tensile strength..$^{18}$ On the other hand, triazine-modified adhesives, ${ }^{30}$ METAC, ${ }^{41}$ triclosan $^{5}$ and MADQUAT ${ }^{28}$ increased the degree of conversion of the adhesive. And the experimental adhesive with BTAM showed similar antibacterial activity to the ones shown within control and reduced the conversion of monomers to polymer. ${ }^{11}$

Another relevant aspect is the adhesive biocompatibility after the incorporation of antimicrobial agents. Monomers present in the adhesives and photo initiators, such as the camphorquinone, are potentially cytotoxic; ${ }^{56}$ nevertheless, the addition of antimicrobial agents must not increase material cytotoxicity. Thus, the DMADDM associated with the $\mathrm{NACP}^{3}$ showed a mild inflammatory response in rat teeth; however, the addition of $0.5 \mathrm{mg} /$ $\mathrm{ml}$ PAI-CuI in Optibond Solo Plus and 0.1 or $0.5 \mathrm{mg} /$ $\mathrm{ml}$ PAACuI reduced cell viability. ${ }^{17}$ Cell viability also reduced with the combination of Transbond XT with bioactive glass $+1 \%$ Ag. ${ }^{26}$ Likewise, when the bio-glass was bound to $0.2 \%$ or $1 \% \mathrm{Zn}$, similar viability was observed within control. ${ }^{26}$ Few studies have addressed this issue; cytotoxicity should, therefore, be further studied to ensure the safety of modified adhesives.

However, antimicrobial agents are not directly added in other studies; only after acid conditioning the dentin is treated to receive the adhesive. In addition to potent antimicrobial activity, ${ }^{46}$ nanoparticles loaded with chlorhexidine present low cytotoxicity in dental pulp stem cells, ${ }^{46}$ with gradual release of the drug into the dentinal tubules. ${ }^{46,47}$ The chlorhexidine is a positively charged molecule that binds to the negatively charged dentin matrix ${ }^{13}$ and is an inhibitor of metalloproteinases, which protects the collagen network and consequently increases adhesion durability. ${ }^{44,46,47}$ Another agent previously used for the application of the adhesive was the grape seed extract, which inhibited secondary caries in the adhesive interface..$^{60}$ On the other hand, it increases the number of operative steps, possibly overlapping the benefits with the increasing clinical time.

Several antimicrobials are incorporated into adhesive systems; however, most of these studies 
are in vitro - they use a single microorganism to test the antimicrobial effect - and are conducted for a short time. Finally, more long-term clinical studies using the microcosm biofilm model are needed, so these functionalized adhesives prove their potential to inhibit secondary caries.

\section{CONCLUSION}

New adhesive and restorative biomaterials should add antibacterial properties. Thus, antibacterial adhesives have been proposed; however, most studies are in vitro and conducted in a short time. Therefore, more long-term clinical studies are needed to evaluate the real effect of these new materials.

\section{REFERENCES}

1. Zhang K, Wang S, Zhou X, Xu HH, Weir MD, Ge Y, et al. Effect of antibacterial dental adhesive on multispecies biofilms formation. J Dent Res. 2015;94(4):622-9. doi: https://doi. org/10.1177/0022034515571416

2. Zhang N, Melo MA, Chen C, Liu J, Weir MD, Bai Y, et al. Development of a multifunctional adhesive system for prevention of root caries and secondary caries. Dent Mater. 2015;31(9):111931. doi: https://doi.org/ 10.1016/j.dental.2015.06.010

3. Li F, Wang P, Weir MD, Fouad AF, Xu HH. Evaluation of antibacterial and remineralizing nanocomposite and adhesive in rat tooth cavity model. Acta Biomater. 2014;10(6):2804-13. doi: https://doi.org/10.1016/j.actbio.2014.02.033

4. Han Q, Li B, Zhou X, Ge Y, Wang S, Li M, et al. Anti-caries effects of dental adhesives containing quaternary ammonium methacrylates with different chain lengths. Materials (Basel). 2017;10(6):643. doi: https://doi.org/10.339o/ma10060643

5. Genari B, Leitune VCB, Jornada DS, Camassola M, Arthur RA, Pohlmann AR, et al. Antimicrobial effect and physicochemical properties of an adhesive system containing nanocapsules. Dent Mater. 2017;33(6):735-42. doi: https:// doi.org/10.1016/j.dental.2017.04.001

6. Yang H, Li K, Yan H, Liu S, Wang Y, Huang C. High-performance therapeutic quercetin-doped adhesive for adhesivedentin interfaces. Sci Rep. 2017;7(1):8189. doi: https://doi. org/10.1038/s41598-017-08633-3
7. Wu T, Li B, Zhou X, Hu Y, Zhang H, Huang Y, et al. Evaluation of novel anticaries adhesive in a secondary caries animal model. Caries Res. 2018;52(1-2):14-21. doi: https://doi.org/10.1159/000481832

8. Yu HH, Zhang L, Yu F, Li F, Liu ZY, Chen JH. Epigallocatechin-3-gallate and epigallocatechin-3-O-(3-O-methyl)gallate enhance the bonding stability of an etch-and-rinse adhesive to dentin. Materials (Basel). 2017;10(2):183. doi: https://doi.org/10.3390/ma10020183

9. Geraldeli S, Soares EF, Alvarez AJ, Farivar T, Shields RC, Sinhoreti MAC, et al. A new arginine-based dental adhesive system: formulation, mechanical and anti-caries properties. J Dent. 2017;63:72-80. doi: https://doi.org/10.1016/j.jdent.2017.05.024

10. Zhou W, Niu LN, Huang L, Fang M, Chang G, Shen LJ, et al. Improved secondary caries resistance via augmented pressure displacement of antibacterial adhesive. Sci Rep. 2016;6:22269. doi: https://doi.org/10.1038/srep22269

11. Centenaro CC, Rostirolla FV, Leitune VC, Parolo CF, Ogliari FA, Samuel SM, et al. Influence of addition of 2-[3-(2H-benzotriazol-2-YL)- 4-hydroxyphenyl] ethyl methacrylate to an experimental adhesive system. Acta Odontol Latinoam. 2015;28(1):728. doi: https://doi.org/10.1590/S1852-48342015000100010

12. AndréCB, Gomes BPFA, DuqueTM, Rosalen PL, Chan DCN, Ambrosano GMB, et al. Antimicrobial activity, effects on Streptococcus mutans biofilm and interfacial bonding of adhesive systems with and without antibacterial agent. Int J Adhes. 2017;72:123-9. doi: https://doi.org/10.1016/j.jadhadh.2016.10.011

13. Pashley DH, Tay FR, Breschi L, Tjäderhane L, Carvalho RM, Carrilho M, et al. State of the art etch-and-rinse adhesives. Dent Mater. 2011;27(1):1-16. doi: 10.1016/j.dental.2010.10.016 14. Ozer F, Blatz MB. Self-etch and etch-and-rinse adhesive systems in clinical dentistry. Compend Contin Educ Dent. 2013;34(1):12-4.

15. Melo MA, Orrego S, Weir MD, Xu HH, Arola DD. Designing multiagent dental materials for enhanced resistance to biofilm damage at the bonded interface. ACS Appl Mater Interfaces. 2016;8(18):11779-87. doi: https://doi.org/10.1021/acsami.6bo1923

16. Chen C, Weir MD, Cheng L, Lin NJ, Lin-Gibson S, Chow LC, etal.Antibacterial activity and ion release of bonding agent containing amorphouscalciumphosphatenanoparticles. Dent Mater.2014;30(8):891901. doi: https://doi.org/10.1016/j.dental.2014.05.025

17. ALGhanem A, Fernandes G, Visser M, Dziak R, Renné WG, Sabatini C. Biocompatibility and bond degradation of polyacrylic acid coated copper iodide-adhesives. Dent Mater. 2017;33(9):e336-47. doi: 10.1016/j.dental.2017.06.010 
18. Su M, Yao S, Gu L, Huang Z, Mai S. Antibacterial effect and bond strength of a modified dental adhesive containing the peptide nisin. Peptides. 2018;99:189-94. https://doi. org/10.1016/j.peptides.2017

19. Wang S, Zhang K, Zhou X, Xu N, Xu HH, Weir MD, et al. Antibacterial effect of dental adhesive containing dimethylaminododecyl methacrylate on the development of Streptococcus mutans biofilm. Int J Mol Sci. 2014;15(7):12791-806. doi: https://doi.org/10.3390/ijms150712791

20. Pupo YM, Farago PV, Nadal JM, Simão LC, Esmerino LA, Gomes OM, et al. Effect of a novel quaternary ammonium methacrylate polymer (QAMP) on adhesion and antibacterial properties of dental adhesives. Int J Mol Sci. 2014;15(5):89989015. doi: https://doi.org/10.3390/ijms15058998

21. Lukomska-Szymanska M, Konieczka M, Zarzycka B, Lapinska B, Grzegorczyk J, Sokolowski J. Antibacterial activity of commercial dentine bonding systems against $E$. faecalis: flow cytometry study. Materials (Basel). 2017;10(5):481. doi: https://doi.org/10.3390/ma10050481

22. Wang L, Xie X, Weir MD, Fouad AF, Zhao L, Xu HH. Effect of bioactive dental adhesive on periodontal and endodontic pathogens. J Mater Sci Mater Med. 2016;27(11):168. doi: https://doi.org/10.1007/s10856-016-5778-2

23. Passariello C, Sannino G, Petti S, Gigola P. Intensity and duration of in-vitro antibacterial activity of different adhesives used in orthodontics. Eur J Oral Sci. 2014;122(2):154-6o. doi: https://doi.org/10.1111/eos.12120

24. Reddy AK, Kambalyal PB, Patil SR, Vankhre M, Khan MY, Kumar TR. Comparative evaluation and influence on shear bond strength of incorporating silver, zinc oxide, and titanium dioxide nanoparticles in orthodontic adhesive. J Orthod Sci. 2016;5(4):127-31. doi: https://doi.org/10.4103/2278-0203.192115

25. Cai X, Han B, Liu Y, Tian F, Liang F, Wang X. Chlorhexidineloaded amorphous calcium phosphate nanoparticles for inhibiting degradation and inducing mineralization of type I collagen. ACS Appl Mater Interfaces. 2017;9(15):12949-58. doi: https://doi.org/10.1021/acsami.6b14956.

26. Lee SM, Kim IR, Park BS, Lee DJ, Ko CC, Son WS, et al. Remineralization property of an orthodontic primer containing a bioactive glass with silver and zinc. Materials (Basel). 2017;10(11):1253. doi: https://doi.org/10.339o/ma10111253

27. Oz AZ, Oz AA, Yazicioglu S. In vivo effect of antibacterial and fluoride-releasing adhesives on enamel demineralization around brackets: a micro-CT study. Angle Orthod. 2017;87(6):841-6. doi: https://doi.org/10.2319/060217-371.1
28. Nascimento PLMM, Meereis CTW, Maske TT, Ogliari FA, Cenci MS, Pfeifer CS, et al. Addition of ammonium-based methacrylates to an experimental dental adhesive for bonding metal brackets: carious lesion development and bond strength after cariogenic challenge. Am J Orthod Dentofacial Orthop. 2017;151(5):949-56. doi: https://doi.org/10.1016/j.ajodo.2016.10.028

29. Yu F, Dong Y, Yu HH, Lin PT, Zhang L, Sun X, et al. Antibacterial activity and bonding ability of an orthodontic adhesive containing the antibacterial monomer 2-methacryloxylethyl hexadecyl methyl ammonium bromide. Sci Rep. 2017;7:41787. doi: https://doi.org/10.1038/srep41787

30. Altmann AS, Collares FM, Leitune VC, Arthur RA, Takimi AS, Samuel SM. In vitro antibacterial and remineralizing effect of adhesive containing triazine and niobium pentoxide phosphate inverted glass. Clin Oral Investig. 2017;21(1):93103. doi: https://doi.org/10.1007/s00784-016-1754-y

31. Schiroky PR, Leitune VCB, Garcia IM, Ogliari FA, Samuel SMW, Collares FM. Triazine compound as copolymerized antibacterial agent in adhesive resins. Braz Dent J. 2017;28(2):196200. doi: https://doi.org/10.1590/0103-6440201701346

32. Sakaguchi RL, Powers JM. Craig materiais dentários restauradores. 13 ed. Rio de Janeiro: Elsevier; 2012. 416 p.

33. Anusavice KJ, Shen C, Rawls HR. Phillips materiais dentários. 12th ed. Rio de Janeiro: Elsevier; 2013. 592 p.

34. Monte Alto R, editor. Reabilitação estética anterior: o passo a passo da rotina clínica. Nova Odessa: Napoleão; 2018. 592 p.

35. Tjäderhane L, Nascimento FD, Breschi L, Mazzoni A, Tersariol IL, Geraldeli S, et al. Strategies to prevent hydrolytic degradation of the hybrid layer: a review. Dent Mater. 2013;29(10):9991011. doi: https://doi.org/10.1016/j.dental.2013.07.016

36. Tjäderhane L. Dentin bonding: can we make it last? Oper Dent. 2015;40(1):4-18. doi: 10.2341/14-095-BL

37. Matos AB, Trevelin LT, Silva BTF, Francisconi-dos-Rios LF, Siriani LK, Cardoso MV. Bonding efficiency and durability: current possibilities. Braz Oral Res. 2017;31(suppl 1):e57. doi: https://doi.org/10.1590/1807-3107BOR-2017.vol31.0057

38. Chen C, Niu LN, Xie H, Zhang ZY, Zhou LQ, Jiao K, et al. Bonding of universal adhesives to dentine: old wine in new bottles? J Dent. 2015;43(5):525-36. doi: https://doi. org/10.1016/j.jdent.2015.03.004

39. Degrazia FW, Leitune VC, Garcia IM, Arthur RA, Samuel SM, Collares FM. Effect of silver nanoparticles on the physicochemical and antimicrobial properties of an orthodontic adhesive. J Appl Oral Sci. 2016;24(4):404-10. doi: https:// doi.org/10.1590/1678-775720160154 
40. Cocco AR, Rosa WLO, Peralta SL, MaskeTT, Silva AF, Hartwig CA, et al. New adhesive system based in metals cross-linking methacrylate. J Mech Behav Biomed Mater. 2018;77:519-26. doi: https://doi.org/10.1016/j.jmbbm.2017.10.010

41. Collares FM, Leitune VCB, Franken P, Parollo CF, Ogliari FA, Samuel SMW. Influence of addition of [2-(methacryloyloxy) ethyl]trimethylammonium chloride to an experimental adhesive. Braz Oral Res. 2017;31:31. doi: https:// doi.org/10.1590/1807-3107BOR-2017.vol31.0031

42. Villat C, Attal JP, Brulat N, Decup F, Doméjean S, Dursun E, et al. One-step partial or complete caries removal and bonding with antibacterial or traditional self-etch adhesives: study protocol for a randomized controlled trial. Trials. 2016;17(1):404. doi: https://doi.org/10.1186/s13063-016-1484-o

43. Deng S, Chung KH, Chan D, Spiekerman C. Evaluation of bond strength and microleakage of a novel metal-titanate antibacterial agent. Oper Dent. 2016;41(3):E48-56. doi: https:// doi.org/10.2341/14-257-L

44. André CB, Gomes BP, Duque TM, Stipp RN, Chan DC, Ambrosano GM, et al. Dentine bond strength and antimicrobial activity evaluation of adhesive systems. J Dent. 2015;43(4):46675. doi: https://doi.org/10.1016/j.jdent.2015.01.004

45. Melo MA, Cheng L, Weir MD, Hsia RC, Rodrigues LK, Xu HH. Novel dental adhesive containing antibacterial agents and calcium phosphate nanoparticles. J Biomed Mater Res B Appl Biomater. 2013;101(4):620-9. doi: 10.1002/jbm.b.32864

46. Priyadarshini BM, Mitali K, Lu TB, Handral HK, Dubey N, Fawzy AS. PLGA nanoparticles as chlorhexidine-delivery carrier to resin-dentin adhesive interface. Dent Mater. 2017;33(7):83046. doi: https://doi.org/10.1016/j.dental.2017.04.015

47. Priyadarshini BM, Selvan ST, Lu TB, Xie H, Neo J, Fawzy AS. Chlorhexidine nanocapsule drug delivery approach to the resin-dentin interface. J Dent Res. 2016;95(9):1065-72. doi: https://doi.org/10.1177/0022034516656135

48. Van Meerbeek B, Yoshihara K, Yoshida Y, Mine A, De Munck J, Van Landuyt KL. State of the art of self-etch adhesives. Dent Mater. 2011;27(1):17-28. doi: https://doi.org/10.1016/j.dental.2010.10.023

49. Perdigão J. Dentin bonding-variables related to the clinical situation and the substrate treatment. Dent Mater. 2010;26(2):e2437. doi: https://doi.org/10.1016/j.dental.2009.11.149.

50. Breschi L, Mazzoni A, Ruggeri A, Cadenaro M, Di Lenarda R, De Stefano Dorigo E. Dental adhesion review: aging and stability of the bonded interface. Dent Mater. 2008;24(1):90101. doi: https://doi.org/10.1016/j.dental.2007.02.009

51. Rosa WL, Piva E, Silva AF. Bond strength of universal adhesives: a systematic review and meta-analysis. J Dent. 2015;43(7):765-76. doi: 10.1016/j.jdent.2015.04.003

52. Cheng L, Zhang K, Weir MD, Melo MA, Zhou X, Xu HH. Nanotechnology strategies for antibacterial and remineralizing composites and adhesives to tackle dental caries. Nanomedicine (Lond). 2015;10(4):627-41. doi: 10.2217/nnm.14.191

53. Li F, Chen J, Chai Z, Zhang L, Xiao Y, Fang M, et al. Effects of a dental adhesive incorporating antibacterial monomer on the growth, adherence and membrane integrity of Streptococcus mutans. J Dent. 2009;37(4):289-96. doi: https://doi. org/10.1016/j.jdent.2008.12.004

54. Padovani GC, Feitosa VP, Sauro S, Tay FR, Duran G, Paula AJ, et al. Advances in dental materials through nanotechnology: facts, perspectives and toxicological aspects. Trends Biotechnol. 2015;33(11):621-36.doi:https://doi.org/10.1016/j.tibtech.2015.09.005

55. Melo MA, Cheng L, Zhang K, Weir MD, Rodrigues LK, Xu HH. Novel dental adhesives containing nanoparticles of silver and amorphous calcium phosphate. Dent Mater. 2013;29(2):199210. doi: https://doi.org/10.1016/j.dental.2012.10.005

56. Dutra-Correa M, Leite A, Cara S, Diniz IMA, Marques MM, Suffredini IB, et al. Antibacterial effects and cytotoxicity of an adhesive containing low concentration of silver nanoparticles. J Dent. 2018;77:66-71. doi: 10.1016/j.jdent.2018.07.010

57. Imazato S. Antibacterial properties of resin composites and dentin bonding systems. Dent Mater. 2003;19(6):449-57. doi: https://doi.org/10.1016/s0109-5641(02)00102-1

58. Imazato S, Tay FR, Kaneshiro AV, Takahashi Y, Ebisu S. An in vivo evaluation of bonding ability of comprehensive antibacterial adhesivesystemincorporating MDPB. Dental Materials. 2007;23(2):1706. doi: https://doi.org/10.1016/j.dental.2006.01.005

59. Cocco AR, Maske TT, Lund RG, Moraes RR. The antibacterial and physicochemical properties of a one-step dental adhesive modified with potential antimicrobial agents. Int J Adhes. 2016;71:748o. doi: https://doi.org/10.1016/j.jjadhadh.2016.08.012

6o. Kim GE, Leme-Kraus AA, Phansalkar R, Viana G, Wu C, Chen $\mathrm{SN}$, et al. Effect of Bioactive Primers on Bacterial-Induced Secondary Caries at the Tooth-Resin Interface. Oper Dent. 2017;42(2):196-202. doi: 10.2341/16-107-L

61. Bisco. All-Bond 2 Primer B: safety data sheet [Internet]. Schaumburg; 2018 [cited 2018 Jul 24]. Available from: https:// bit.ly/3d9zQ8f

62. Daood U, Swee Heng C, Neo Chiew Lian J, Fawzy AS. In vitro analysis of riboflavin-modified, experimental, two-step etch-and-rinse dentin adhesive: Fourier transform infrared spectroscopy and micro-Raman studies. Int J Oral Sci. 2014;7(2):110-24. doi: https://doi.org/10.1038/ijos.2014.49

63. 3M. 3M Unitek Transbond XT Light Cure Adhesive Kit (712030, 712-035): safety data sheet [Internet]. Sant Paul; 2016 [cited $2018 \mathrm{Jul}$ 24]. Available from: https://bit.ly/2Mom8ZF 64. Delaviz Y, Liu TW, Deonarain AR, Finer Y, Shokati B, Santerre P. Physical properties and cytotoxicity of antimicrobial dental resin adhesives containing dimethacrylate oligomers of Ciprofloxacin and Metronidazole. Dent Mater. 2019;35(2):229-43. doi: 10.1016/j.dental.2018.11.016 